\title{
Inland-coastal demographic transformations in a karst area: a case study of the surroundings of Krka National Park (Croatia)
}

\author{
TELBISZ Tamás ${ }^{*}$ (D)https://orcid.org/oooo-0003-4471-2889; $\gg$ e-mail: tamas.telbisz@ttk.elte.hu

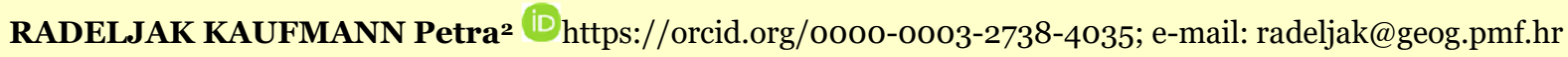 \\ BOČIĆ Neven² (Dhttps://orcid.org/oooo-0001-6102-5330; e-mail: nbocic@geog.pmf.hr \\ * Corresponding author \\ 1 Department of Physical Geography, Eötvös Loránd University, Pázmány Péter sétány 1/C, Budapest 1117, Hungary \\ 2 Department of Geography, Faculty of Science, University of Zagreb, Marulicev trg 19/II, Zagreb 10ooo, Croatia
}

Citation: Telbisz T, Radeljak Kaufmann P, Bočić N (2022) Inland-coastal demographic transformations in a karst area: a case study of the surroundings of Krka National Park (Croatia). Journal of Mountain Science 19(2). https://doi.org/10.1007/s11629-021-7032-8

(C) The Author(s) 2022.

\begin{abstract}
According to geographic possibilism, environment does not determine socio-economic development. However, the environment sets certain constraints and limitations for development. How do natural settings influence population dynamics? In this study, we examine this question using the example of Šibenik-Knin County, which includes Krka National Park (NP) with a GIS-based statistical approach. The following parameters represent natural factors: elevation, slope, distance from water, and proportion of karst areas. In addition, distance from Krka NP was also added as an independent seminatural factor (despite the fact that it is a social construction). The dependent social parameters are population density for selected historical dates, population change, year of maximum population, natural increase, migration, and age index. The analysis units are the 199 settlements found in the county, and the 20 local administrative units (LAU2). The study period can be divided into five phases: from the first census in 1857 to 1921, there was a slow increase in most settlements; then a relatively constant phase up to 1961 (some settlements began shrinking in this period); a slow decrease until 1991; a
\end{abstract}

Received: 30-Jul-2021

Revised: 01-Dec-2021

Accepted: 05-Jan-2022 rapid decrease during the next decade; and relative stabilisation to present day. These processes were also accompanied by significant inner and outer migrations. As for the relationships between natural and demographic factors, we found that although the coastal-inland area dichotomy is dominant in the study area, elevation has the highest correlation with most population parameters. However, distance from water is also significantly correlated with population change and migration in certain periods. In the inland areas, there are statistically significant differences between the demographic processes of fully-karstic and partially-karstic areas, while in the coastal zone, the karst effect is overshadowed by other social processes. The impact of Krka NP on the demographic characteristics of the surrounding settlements was statistically not detectable. Our final conclusion is that correlations between natural and population parameters are low or moderately strong but statistically significant in many cases, thus the basic principles of geographic possibilism are valid for the area.

Keywords: Geographic possibilism; Karst; National park; Population density; Migration 


\section{Introduction}

One of the central themes of geographic thinking is the relationship between natural settings and social factors (Massey and Allen 1984). This relationship is not deterministic, as the theory of geographical determinism erroneously argued, rather it is better to say that nature provides opportunities for society to live in. This notion is known as geographical possibilism (Gregory et al. 2009; Mercier 2009). In the age of Vidal de la Blache, geographical possibilism was of a qualitative, descriptive nature, but in the second half of the $2 \mathrm{O}^{\text {th }}$ century, and especially in the $21^{\text {st }}$ century, the detailed statistical analysis of relationships between natural and demographic factors has become possible thanks to GIS tools. Part of this research includes so-called hypsographic demographics (Small and Cohen 2004; Patterson and Doyle 2011).

The relationship between topographic, geological, hydrographic factors and certain demographic characteristics has already been studied in a number of areas, including the Sudety Mountains in Poland (Latocha 2012), Montenegro (Telbisz et al. 2014), the Gömör-Torna Karst in Hungary and Slovakia (Telbisz et al. 2015), the Apuseni Mountains in Romania (Telbisz et al. 2016), Kastamonu Forest in Turkey (Buğday and Özden 2017), the Caucasus (Kohler et al. 2017), the Sarajevo Region in Bosnia and Herzegovina (Lukić-Tanović et al. 2019), and Zlatibor and Tara mountains in Western Serbia (Telbisz et al. 2020a). Based on the aforementioned, it can be stated that there is often a medium or even strong statistical relationship between elevation and population density, or between elevation and population change. An important finding, however, is that both the strength and the direction of the relationship changed throughout history in some of the areas studied, as there were extensive periods when mountain populations grew and people claimed more areas in the mountains; but mainly from the $20^{\text {th }}$ century onwards, depopulation of the mountains has been more dominant, which has been described and studied in many mountainous areas. The study of this phenomenon is important for both theoretical and practical reasons, as depopulation and ageing pose a number of social problems (e.g. maintaining schools, public transport facilities, and many other local services) for small settlements (MacDonald et al. 2000; Childs et al. 2014; Wang et al. 2019).
Among the geological factors, many features could be examined, however, karst regions are at the forefront of our interest. The peculiarities of karst areas are that due to water infiltration: the higher areas suffer from water shortages and poor soil and, thus, have poor agricultural conditions (Ciglič et al. 2012), and they are traditionally more characterised by animal husbandry. This means that their population density has been historically low, and even today they are often characterised by the process of depopulation (Gams 1993; Pejnović and HusanovićPejnović 2008; Telbisz et al. 2015). However, such areas are also rich in special morphological elements (caves, gorges, dolines, collapse dolines), botanical values (Ewald 2003), and cultural heritage (Du et al. 2008). This has resulted in many karst areas being declared protected areas. In Europe, a quarter of the national parks and almost half of the geoparks are partly or wholly associated with karst areas (Telbisz and Mari 2020); and globally, karst areas play a significant role within geoparks (Ruban 2018) and the World Heritage List (Hamilton-Smith 2007).

Although the unfavourable conditions of karsts for human settlement have already been recognised by several authors, only few studies have so far dealt with the quantitative study of this topic (Pejnovic and Husanović-Pejnović 2008; Telbisz et al. 2014, 2015, 2016; Buğday and Özden 2017; Lukić-Tanović et al. 2019). Moreover, in terms of geographical possibilism, the internal context of social development (history, form of government, economic situation, etc.) are much more pronounced in the formation of demographic characteristics than the indirect effects of the underlying natural factors. Therefore, a number of studies in sample areas with different levels of social development are needed to identify the indirect (i.e. by no means deterministic) effect of natural factors on demographic indicators in karst areas, and to determine the statistical strength and nature of the relationships. We intend to take a step in this direction by examining the sample area presented in this article.

Taking into consideration the above aim, we chose a study area where the topography varies significantly from sea level to the high mountain category; it is mostly a karst area with a well-known national park at its centre. This sample area is located in Croatia and encompasses Šibenik-Knin County, which includes Krka National Park (Fig. 1)-famous for its travertine limestone waterfalls. In addition to 


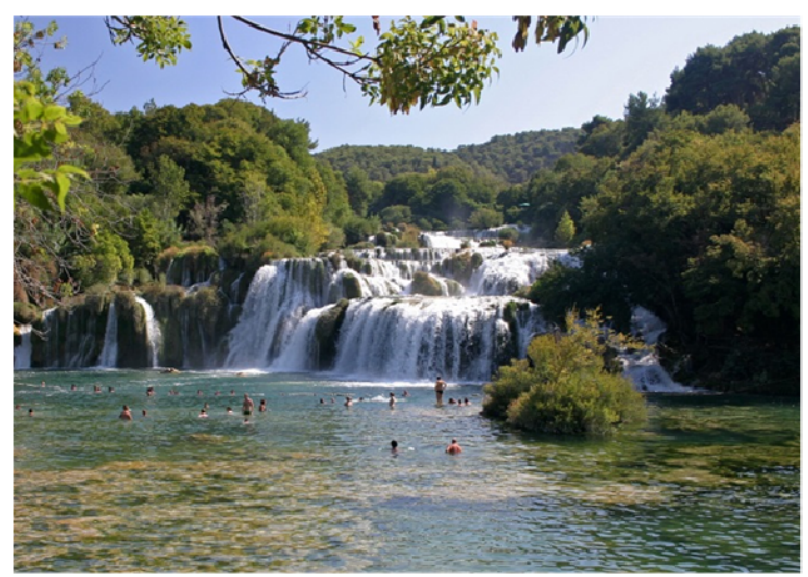

Fig. 1 Travertine waterfalls in Krka NP (Croatia).

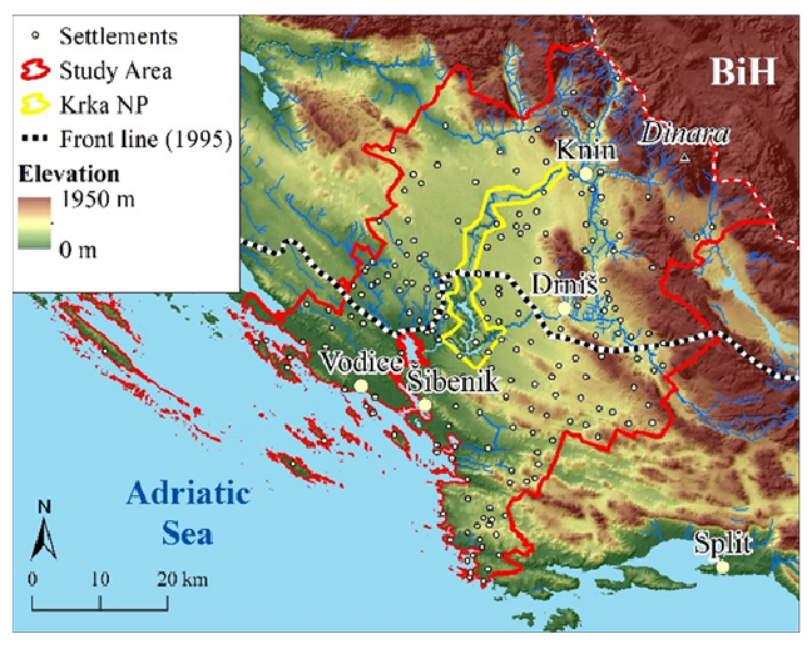

Fig. 2 Topographic map of the study area (ŠibenikKnin County) with the boundary of Krka National Park. BiH: Bosnia and Herzegovina.

the aforementioned factors, another important aspect is that we can observe the change of each factor along a section that stretches from the coast to the interior.

Our aim is to test whether there are statistical relationships between natural and demographic factors in the sample area, using GIS and statistical software. Our initial hypotheses are as follows:

- The social-demographic processes of the coastal and inland areas are significantly different even within such a relatively small area.

- There are significant differences between the demographic processes of karst and non-karst (partially-karst) areas.

- Demographic characteristics are influenced by elevation and the topographic dissection of the area.

- Distance from surface waters is also statistically related to demographic factors.
- The national park has an impact on the demographic processes of the surrounding settlements.

- The aforementioned statistical relationships are temporally varied and of moderate intensity.

\section{Study Area}

The study area is Šibenik-Knin County. It is located in the central part of Littoral Croatia and covers 2,984 km² (Fig. 2). There are 199 settlements, which form 20 local administrative units (LAU2). Its total population, according to the latest census data (2011), is 109,375, and is in decline. Its population density is on average 36.8 people $/ \mathrm{km}^{2}$, which means that it is a relatively sparsely populated area, even if compared to the whole of Croatia (75.8 people $/ \mathrm{km}^{2}$ ). Topographically, the area extends from sea level to the highest point in Croatia: Dinara (Sinjal) Mountain $(1,831 \mathrm{~m})$. In the south-eastern part of the area, there are folded ridges which increase in elevation towards the interior of the mainland. The mountain ridges have a characteristic of NW-SE "Dinaric" orientation. Northwest of the town Drniš, there are undissected, flat, karst plateaus at elevations of $200-300 \mathrm{~m}$. The towns Knin and Drniš are located on the edges of karst poljes. These large, more or less closed depressions represent a characteristic landform type of Dinaric Karst.

The coastal zone is highly indented, and 11 settlements are located on islands. The actual number of islands is much higher, but the smaller ones are uninhabited, or at least do not have an independent settlement. Well-karstified Mesozoic (mostly Cretaceous) limestones and dolomites cover $89 \%$ of the area (Fig. 3). The rest are predominantly Cenozoic, non-karstic sedimentary rocks, the majority of which are Quaternary sediments, mainly lining the bottom of the karst poljes.

Socio-economic development of the study area in the second half of the $20^{\text {th }}$ century was determined by industrialisation and tourism development in the coastal zone, and accompanied by a significant increase in the construction of holiday homes up to the 1990s. The islands and inland areas have often been characterised by depopulation and lagging behind in economic development; this was less pronounced for Drniš and Knin as more important centres at the local level (Glamuzina and Glamuzina 


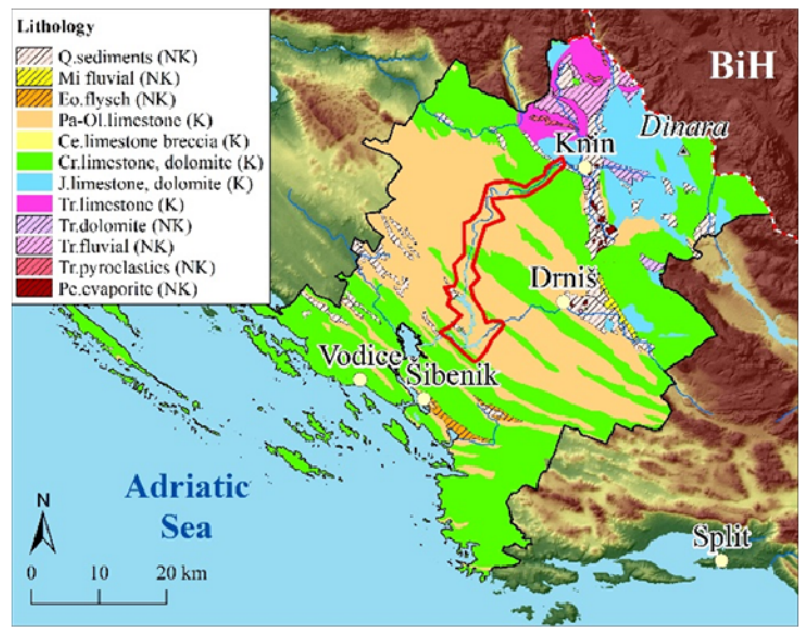

Fig. 3 Simplified lithological map of the study area. K: karstic, NK: non-karstic (marked with diagonal line pattern). Q: Quaternary, Mi: Miocene, Eo: Eocene, PaOl: Paleocene-Oligocene, Ce: Cenozoic, Cr: Cretaceous, J: Jurassic, Tr: Triassic, Pe: Permian. Source: Geological map of Croatia 1:300,000 by Croatian Geological Survey (CGS 2009). BiH: Bosnia and Herzegovina.

1996, Lukić 2012, Opačić 2012, Pejnović 2004, Radeljak Kaufmann 2016). On the whole, politicaleconomic change along with the effects of the 1991-1995 Croatian War of Independence brought about a decline in the production sector of the economy and a predominant orientation towards the service sector. The area has undergone increased development of tourism, especially in the coastal zone (together with the islands), with a spillover effect towards the inland areas visible in recent years (Radeljak Kaufmann 2020).

Krka National Park lies roughly in the middle of the county. It was founded in 1985 and currently covers an area of $109 \mathrm{~km}^{2}$. Tourism in Krka NP has developed extremely dynamically. The number of visitors reached its first peak in 1988 with 385,000. After post-war recovery, the number of visitors gradually increased, and 1.354 million visitors were recorded in 2018. Due to overtourism, a visitor restriction of 10,000 people per day had to be introduced at Skradinski buk (Skradin waterfalls), which is the most visited part of Krka NP (Radeljak Kaufmann 2020).

Demographic processes in the area are presented in detail in the results section to avoid repetition. However, population ageing and depopulation are a typical problem throughout Croatia, and Šibenik-Knin County has one of the oldest populations in the country (Mrđen and Barić 2016).

\section{Data and Methods}

For our study, topographic data were taken from the SRTM database (Rabus et al. 2003). We used the 1 arc-second version of the SRTM dataset, which means that the original pixel resolution was 1 arc-second, and resampled to $30 \mathrm{~m}$ resolution when the dataset was reprojected to UTM $33 \mathrm{~N}$ (WGS84). Based on this, we calculated the elevation value $(Z)$ of the centre of the settlements and the mean slope of the area within the administrative boundaries of the settlements (MeanSlope), which include the inhabited area and the surrounding lands as well. For the locations of settlements, rivers and other topographic elements, we used the Digital Atlas of Croatia (GISData 2008) database.

Lithological data were taken into consideration based on the geological map (CGS 2009). Each lithological unit was categorised into either "karstic" or "non-karstic" class based on rock characteristics and the field appearance of karst forms. Subsequently, we determined the percentage of karst areas (MeanKarst) within the administrative boundaries of the settlements. As the vast majority of the area is karst, there are only few settlements that do not have karstic rocks at all within their entire administrative area. Therefore, most areas are mixed or completely karstic in this respect. It is typical of many "mixed karst" settlements located near Quaternary sediments with relatively more fertile soils that the more fertile parts of the area were used for agriculture in the past, while the houses of the settlement were built on the karstic parts. Thus, settlements were classified into either "fully-karstic" or "partially-karstic" classes. The MeanKarst threshold between the two classes was set to $80 \%$, taking into account qualitative reasons and the distribution of the data. The majority of settlements (78\%) were classified as "fully-karst" (i.e. MeanKarst $>80 \%$ ), while the rest were categorised as "partially-karst".

The distance from the sea (SeaDist) was determined by GIS tools as the Euclidean distance based on the centre of the settlements and the location of the coastline. Based on this distance, we created the "coastal" and "inland" categories; the SeaDist threshold in this case was $10 \mathrm{~km}$. The threshold of $10 \mathrm{~km}$ was selected because maps of different variables "suggested" that the settlements directly at the coast, and also the "second line" of settlements, have different demographic 
characteristics than the settlements further inland. The width of this zone including the "second line" of settlements is about $10 \mathrm{~km}$.

In terms of access to water, we also took into account both the drainage network of the area and the distance from the sea. It is important to note that the drainage network of the area is extremely heterogeneous (Fig. 2). It is dense in areas consisting of non-karstic rocks, but rare or absent in karst terrains. Rivers or streams occur in karst areas in valleys (with steep edges but broad widths), mainly in the area of Krka NP, or in other areas, e.g. along the synclines, where smaller watercourses are found, which typically carry water only periodically. In our analysis, the water distance (WaterDist) is the shorter of the distances of the settlement centre from the drainage network and/or from the sea.

As for the population data, we collected census data on settlements (CBS n.d. a, CBS 2013). The first census in the study area took place in 1857 , and the most recent in 2011; a census was carried out every 10 years on average. Based on the data, we determined the population density values at different times and the year of the maximum population for each settlement. Population changes were expressed as the ratio of the population at two different dates, so, for example, PopRatio 1961to1857 is equal to the ratio of the population in 1961 to the population in 1857 . To make the magnitude and direction of the change easier to understand, the value was also expressed as a percentage and $100 \%$ was subtracted from the ratio value (e.g. PopChange 1857to1961 equals PopRatio 1961 to1857 - 100\%), so positive values express population growth and negative values express population loss.

From the 1970s onwards, more detailed demographic data have been available (CBS n.d. b), based on which we calculated the relative values of natural increase and migration for settlements for 10year long cycles (NatIncr, Mig values). Relative values were obtained by dividing the absolute values summed over ten years by the total population of the baseline year. The settlements of the study area are characterised by ageing, thus the AgeIndex value was also calculated as the proportion of the population over 60 and under 20 years of age.

The correlations between the parameters were examined with the Spearman correlation coefficient. We omitted the three traditionally leading urban centres (Šibenik, Knin, Drniš) from the correlation calculations due to their distorting effect and evaluated them separately. According to the last census data (2011), Šibenik had 34,302 inhabitants, Knin had 10,633, and Drniš had 3,144, which means $31.4 \%, 9.7 \%$, and $2.9 \%$ of the total population, respectively. It should be noted that since 2011, the population of Vodice (as a LAU2) has become slightly larger than the population of declining Drniš. Nevertheless, the population density values of Vodice are still not extreme, so we did not exclude this settlement from the dataset for correlation calculations. This brings the number of settlements to 196 (excluding the aforementioned), which means that the Spearman correlation coefficient is statistically significant if the value is above 0.15 or below -0.15. In the case of 196 settlements, of course, due to the many individual cases, the correlations are less pronounced, so we used a second, complimentary approach. We arranged the settlements into bins according to selected parameters and calculated mean values for all bins. According to the different parameters, 11-17 bins were formed (depending on how the class boundaries were rounded). For the binned data, however, due to the smaller number of items, the significance thresholds for correlations are higher, ranging from 0.48 (in the case of 17 data) to 0.6 (in the case of $\mathbf{1 1}$ data).

In addition, Kolmogorov-Smirnov tests were used in order to examine certain hypotheses. We chose this type of test, because it is suitable for comparison with empirical distributions even if they are not normal. To detect the effect of karst, we compared the "partially-karst" and "fully-karst" areas. However, these comparisons would be strongly distorted by other variables, mainly the distance from the coast, so the settlements were divided into two classes (coastal and inland) and the karst effect was examined separately for each class. We also investigated the effect of Krka National Park, and distance to NP (NPdist) was calculated for each settlement as the distance between the settlement centre and the NP boundary. Settlements deemed "close to Krka NP" are those less than $2 \mathrm{~km}$ from Krka NP. To eliminate the effect of other factors, we put only those settlements which have a similar distance from the sea and a similar altitude range, i.e. the SeaDist value is between $8.6 \mathrm{~km}$ and $42 \mathrm{~km}$ and the $Z$ value is between $\mathrm{o} \mathrm{m}$ and $370 \mathrm{~m}$, into the control group. Finally, the effects of war were also examined. A significant part of the inland area was occupied 
Table 1 Acronyms used in this paper

\begin{tabular}{|c|c|c|}
\hline Acronym & Definition & Data source \\
\hline$Z$ & Elevation of settlement centre & $\begin{array}{l}\text { SRTM } \\
\text { Gisdata } 2008\end{array}$ \\
\hline MeanSlope & $\begin{array}{l}\text { Mean slope of the area within the administrative } \\
\text { boundaries of the settlement }\end{array}$ & $\begin{array}{l}\text { SRTM } \\
\text { Gisdata } 2008\end{array}$ \\
\hline MeanKarst & $\begin{array}{l}\text { Percentage of karst areas within the administrative } \\
\text { boundaries of the settlement }\end{array}$ & $\begin{array}{l}\text { geological map (CGS 2009); } \\
\text { Gisdata } 2008\end{array}$ \\
\hline SeaDist & Distance of the settlement centre to the coastline & Gisdata 2008 \\
\hline WaterDist & $\begin{array}{l}\text { The shorter of the distances of the settlement centre to } \\
\text { the drainage network and/or the sea }\end{array}$ & Gisdata 2008 \\
\hline NPDist & Distance of the settlement centre to Krka NP & Gisdata 2008 \\
\hline PopDens & Population density & $\begin{array}{l}\text { census data } \\
\text { (CBS n.d. a, CBS 2013) }\end{array}$ \\
\hline PopRatio YYtoXX & $\begin{array}{l}\text { Ratio of the population in year YY to the population in } \\
\text { year XX }\end{array}$ & $\begin{array}{l}\text { census data } \\
\text { (CBS n.d. a, CBS 2013) }\end{array}$ \\
\hline PopChange XXtoYY & PopRatio YYtoXX - 100\% (in percent) & $\begin{array}{l}\text { census data } \\
\text { (CBS n.d. a, CBS 2013) }\end{array}$ \\
\hline NatIncr XXtoYY & $\begin{array}{l}\text { Relative value of natural increase for a settlement } \\
\text { between year XX and year YY }\end{array}$ & demographic data (CBS n.d. b) \\
\hline Mig XXtoYY & $\begin{array}{l}\text { Relative value of migration for a settlement between } \\
\text { year XX and year YY }\end{array}$ & demographic data (CBS n.d. b) \\
\hline AgeIndex & $\begin{array}{l}\text { Proportion of the population over } 60 \text { and under } 20 \\
\text { years of age }\end{array}$ & demographic data (CBS n.d. b) \\
\hline
\end{tabular}

from 1991 to 1995 (north of the frontline as shown in Fig. 1, Rakić and Dubravica 2009). Therefore, we tested the differences between occupied and nonoccupied settlements in "fully-karst" inland areas. (For "partially-karst" inland areas, there were only two settlements that were not occupied, making the comparison between occupied and non-occupied settlements for "partially-karst" areas meaningless.)

To illustrate the spatial distribution of demographic factors, we created maps for the study area using GIS tools. GIS analysis and visualisation were carried out using ArcGIS 10.3, whereas statistical analysis was performed in MS Excel 365 and Statgraphics Centurion 16.1.

The acronyms used in this paper are presented in Table 1.

\section{Results}

\subsection{Long-term population dynamics}

The long-term population changes of the whole study area over a period of roughly 150 years are presented based on the 20 LAU2 (Fig. 4). The population of the whole area showed relatively slow growth from the beginning of the interval to 1961, at a generally balanced pace. From then on, population loss was characteristic, initially at a slow pace followed by a sudden drop in the period of 1991-2001.
This was the decade when Yugoslavia disintegrated and Croatia became independent. Independence was accompanied by severe struggles and one of the early areas of conflict was within the study region (especially the Knin area), owing to the significant Serb minority presence in the population. During the War, many people fled to other parts of Croatia or abroad. In addition, the transition to a market economy took place during this decade as well, which also caused economic problems that, in turn, contributed to depopulation. The process of depopulation has slowed since 2001 but has not completely ceased.

The two largest LAU2 in the area (Šibenik, Knin)

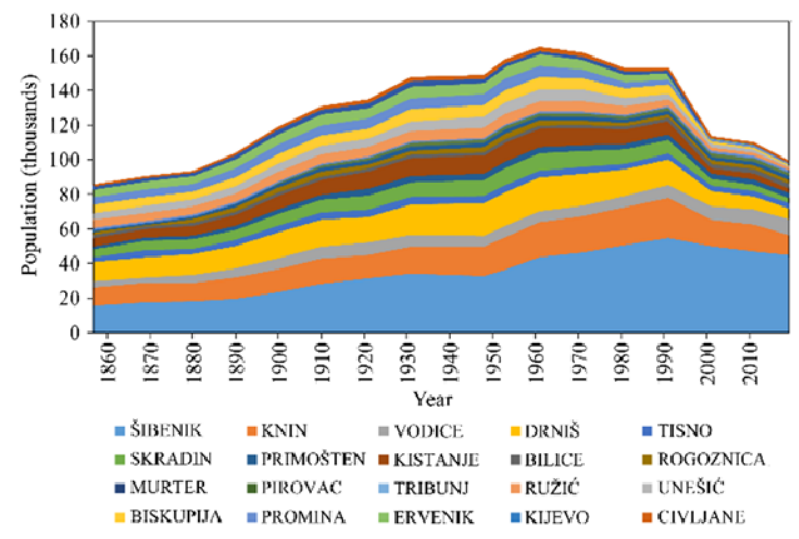

Fig. 4 Long-term population changes in the study area based on census data covering 1857-2019, except 2019, which is an official estimation for LAU2s (CBS n.d. a, CBS 2013, CBS 2020). 
peaked in 1991, but the former second largest LAU2 (Drniš) has been declining since 1961, and has been gradually overtaken by the emerging Vodice (since 2011). Of the larger settlements, coastal Vodice is the only one that has had continual growth since 1961, even during the 1990s. It can be clearly seen in Fig. 5 that, from the coast to the inland, the LAU2s typically reached their population peak earlier. However, there are exceptions in both directions: populations of some smaller LAU2s on the coast peaked as early as 1921 and 1931, while the population of Knin (the LAU2 of the second largest town) on the mainland grew until 1991.

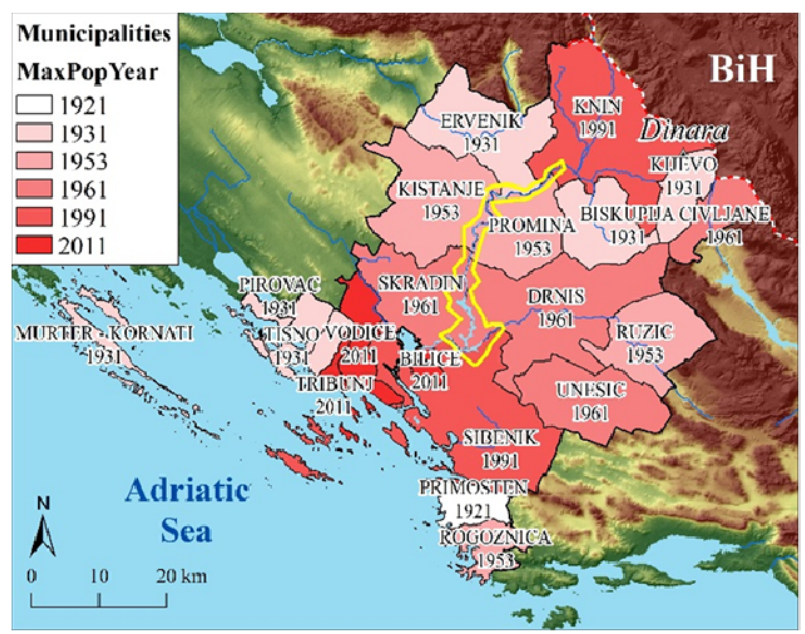

Fig. 5 Year of maximum population (according to census data) for the LAU2s of Šibenik-Knin County. $\mathrm{BiH}$ : Bosnia and Herzegovina.

Based on the aforementioned general population change curve, we selected three key years: 1857, 1961, and 2011, which are highlighted in the further demographic calculations (in terms of population density and population change indicators). In addition, changes during the war decade (1991-2001) are also included in the analysis.

The aforementioned changes can also be well illustrated by changes in population density (Fig. 6). In 1857 , the whole area was characterised by lower population density ( 28.5 people $\left./ \mathrm{km}^{2}\right)$, and the spatial pattern consisted of one or two settlements on the immediate coast with exceptionally high population density, while the interior areas were characterised by a relatively even, moderate population density. By 1961, the total population density reached its maximum (55.2 people $/ \mathrm{km}^{2}$ ) and became spatially well-balanced, with the contrast of the coastal and inland areas at its lowest. By 2011, the average population density had fallen sharply (36.8

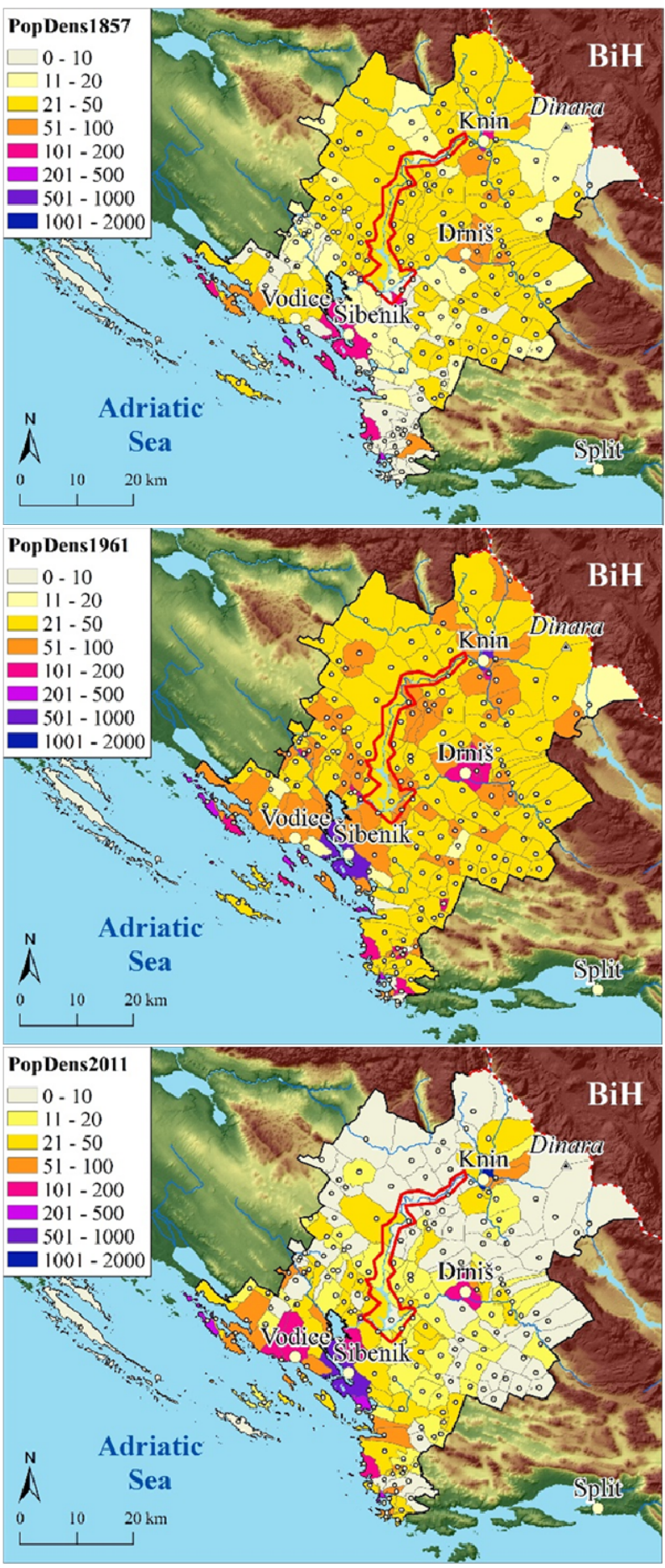

Fig. 6 Population density of the study area in 1857 (upper), 1961 (centre), and 2011 (bottom). BiH: Bosnia and Herzegovina.

people $/ \mathrm{km}^{2}$ ) and "the tables turned", so to speak. The interior emptied (except for the two major centres, Knin and Drniš), while the population density of the coastal settlements increased. This process is particularly well-expressed if we calculate the integrated population density for the 66 settlements 
in the coastal zone and the 133 settlements in the interior (Fig. 7). In 1857, the difference was relatively small, 34.2 people $/ \mathrm{km}^{2}$ on the coast and 26.7 people $/ \mathrm{km}^{2}$ in the interior. By 1961 , both values had increased, but the difference had also grown: 82.5 people $/ \mathrm{km}^{2}$ in the coastal zone compared to 45.8 people $/ \mathrm{km}^{2}$ in the interior. By 2011, the population density on the coast increased slightly to 90.2 people $/ \mathrm{km}^{2}$, while it decreased significantly to 17.8 people $/ \mathrm{km}^{2}$ in the interior areas. The historically shifting population trends can be clearly recognised in Fig. 8. While in the first half of the study period, inland areas increased, and the whole area was characterised by a general growth, the narrow coastal strip and some of the islands showed a population decrease. In the second part of the period under review, an almost reversed picture emerged. Population in the large internal areas decreased, with the exception of the two larger towns (Knin, Drniš) which maintained or slightly increased their population (at the expense of neighbouring smaller settlements). In contrast, the population of coastal settlements has increased in general, though most of the islands and even some mainland settlements have started to decline.

\subsection{Changes in natural increase and migration trends during the last 50 years}

On the one hand, population changes are influenced by natural increase, but migrations have played an even more important role within the sample area and during the last 50 years. The details of these can be traced back to our settlement-level data from the 1970s onwards, and we can conclude that there have been significant changes in both factors on a decadal scale (Fig. 9). Natural change showed a mixed picture in the 1970s, which means that, in addition to the growing urban centres, the value of natural change was positive in roughly half of the small settlements at that time. By the 1980s, the deteriorating trend had already begun and, besides the towns, only a few rural settlements with positive natural change remained. In the 1990s, the decline was already decisive and the growth stopped even in the largest towns, and by the 2000 s the countryside was already experiencing a very strong decline, along with the urban centres of Šibenik and Drniš.

Part of the migration process refers to migration within the territory, and the other part to outward migration to other parts of Croatia and abroad. In

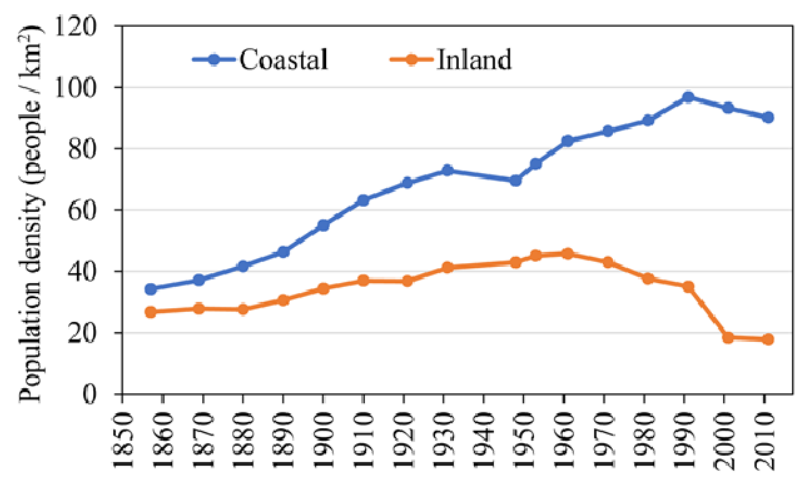

Fig. 7 Coastal-interior comparison of population density changes from 1857 to 2011.

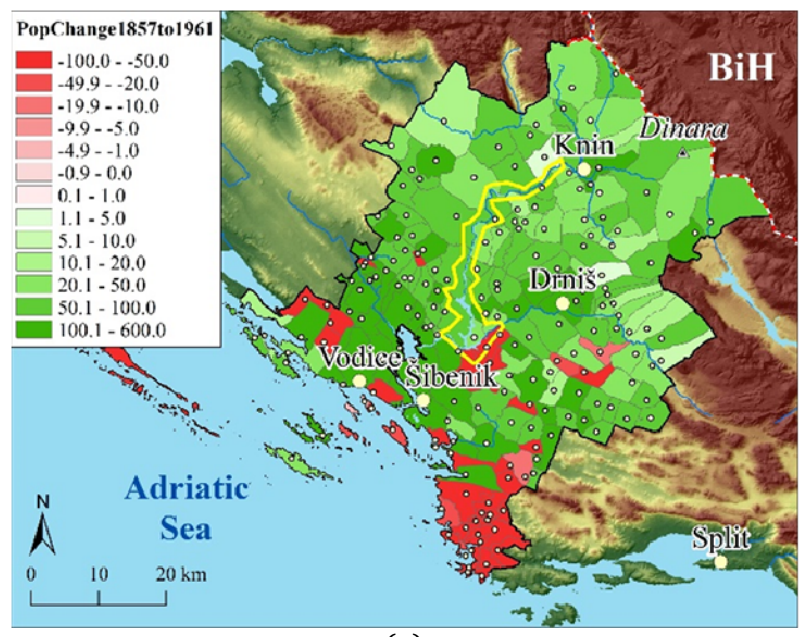

(a)

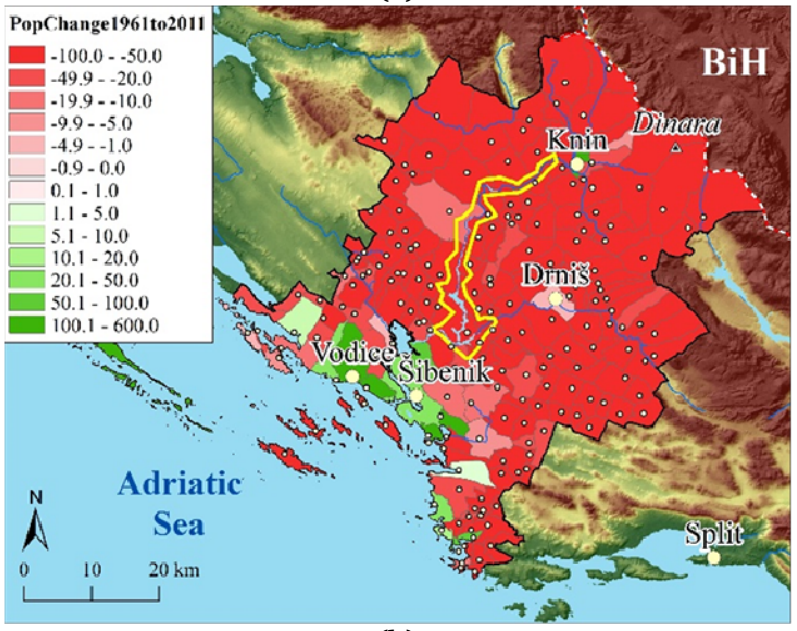

(b)

Fig. 8 Maps of population changes (in percent) from 1857 to 1961 (A) and from 1961 to 2011 (B). BiH: Bosnia and Herzegovina.

addition, migration from outside to the study area also occurred in certain cases. In fact, out-migration was already very common throughout the county in the 1970s, except for the central part of the coast and the two main inland towns (Fig. 10). The 1980 os 


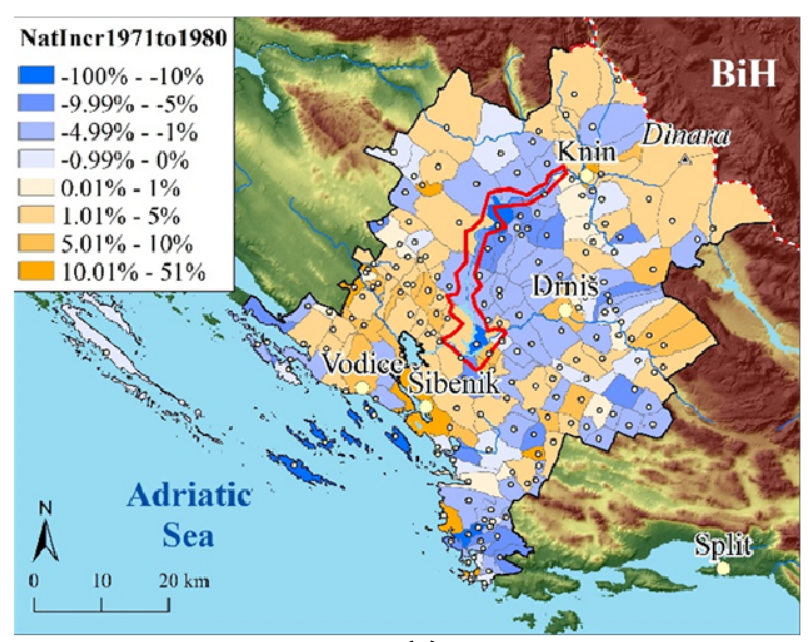

(a)

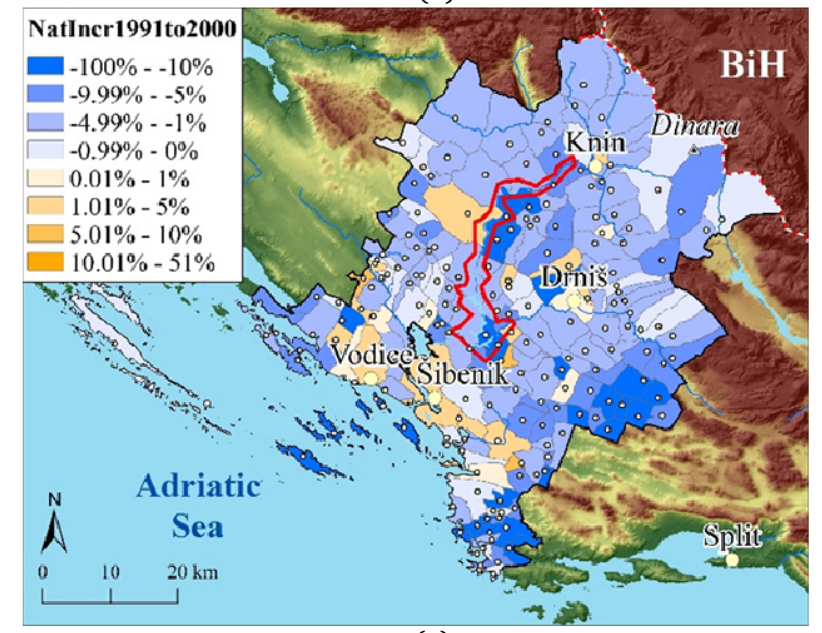

(c)

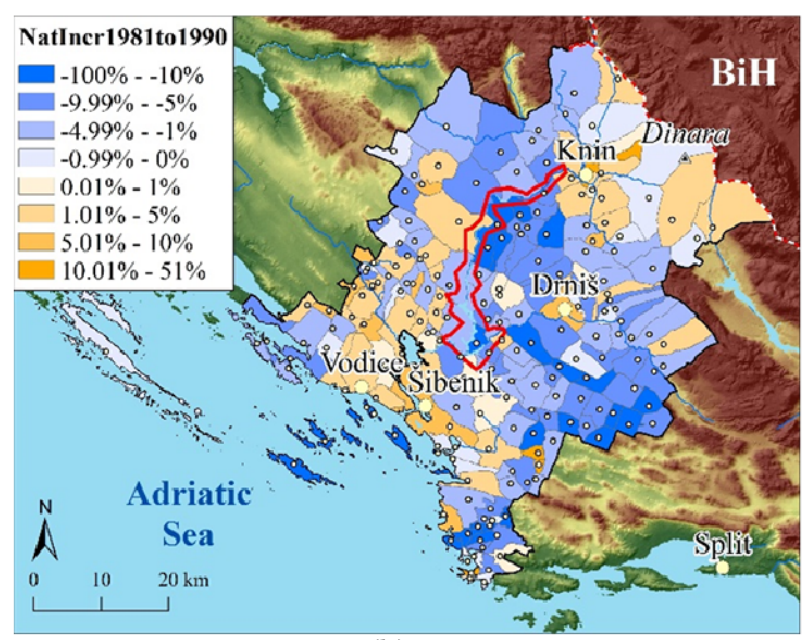

(b)

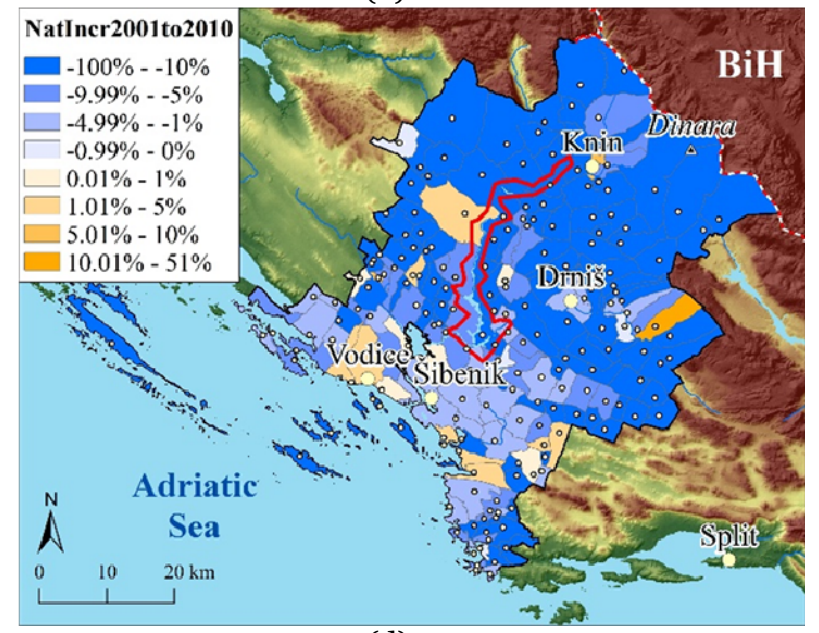

(d)

Fig. 9 Maps of natural increase relative values calculated by decade. A) 1971 to 1980 , B) 1981 to 1990 , C) 1991 to 2000, D) 2001 to 2010. BiH: Bosnia and Herzegovina.

brought about a positive change, a reduction in outmigration from settlements, that remained significant only in rural settlements with higher topography. Balanced migration was characteristic for many settlements, and a broad band of the coastal zone recorded a surplus. The 1990 s brought about a radical change, mainly due to the Croatian War of Independence, which severely affected this area. Thus, emigration from internal areas is uniform and significant. Some of the refugees were taken up by coastal settlements and even islands, but a significant part of the Serb minority went to Serbia. In the 2000s, the picture is again completely different. Post-war resettlement began, although in some cases it was not the former residents who returned, rather Croats settling here from other parts of the former Yugoslavia (especially from Bosnia and Herzegovina; Mrđen and Barić 2016). In this way, a coherent zone with a positive migration balance formed in the inner areas. In the vicinity of Drniš and to the south, as well as in some parts of Krka NP, however, the balance of migration is still negative; surprisingly, this is also the case in Šibenik, the largest coastal town. Furthermore, resettlement has an interesting spatial dimension that is hidden by statistics. While the better soils formed on the Quaternary sediments of the poljes were previously reserved for agricultural purposes, this was no longer a consideration at the time of the resettlement in the $21^{\text {st }}$ century and even earlier, in the last decades of the $20^{\text {th }}$ century, thus residential areas have been increasingly built on poljes as well. As for migration processes, it should also be mentioned (which is not yet visible in our present data) that outmigration and emigration have continued in recent years, with a new wave following Croatia's accession to the European Union in 2013 (Radeljak Kaufmann 2020). 


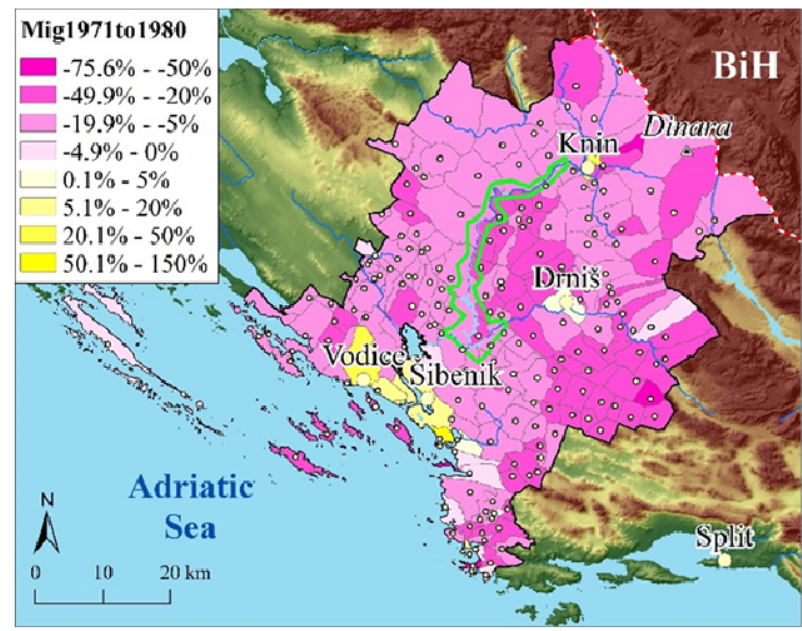

(a)

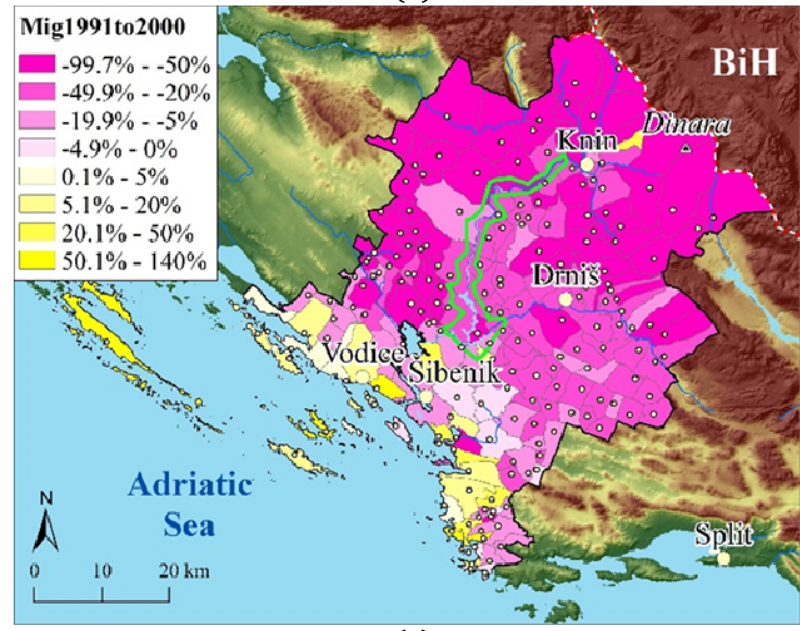

(c)

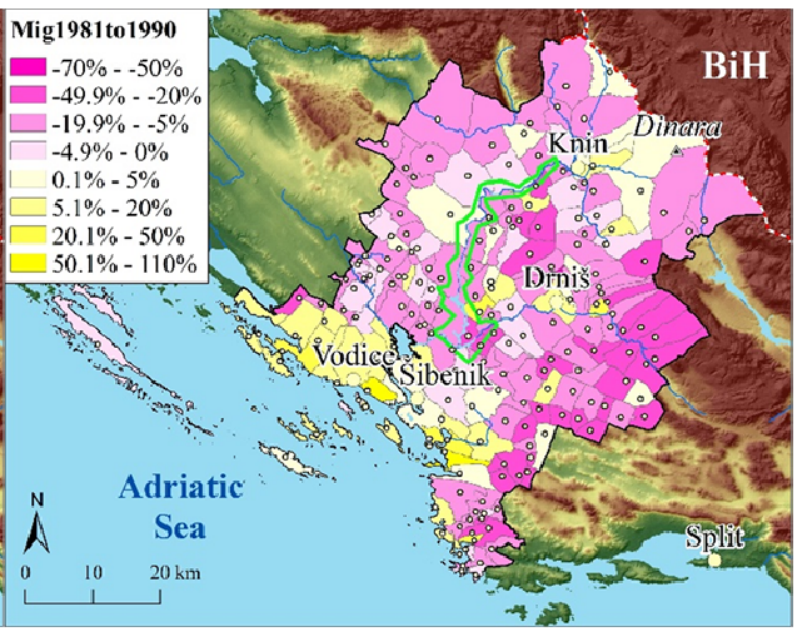

(b)

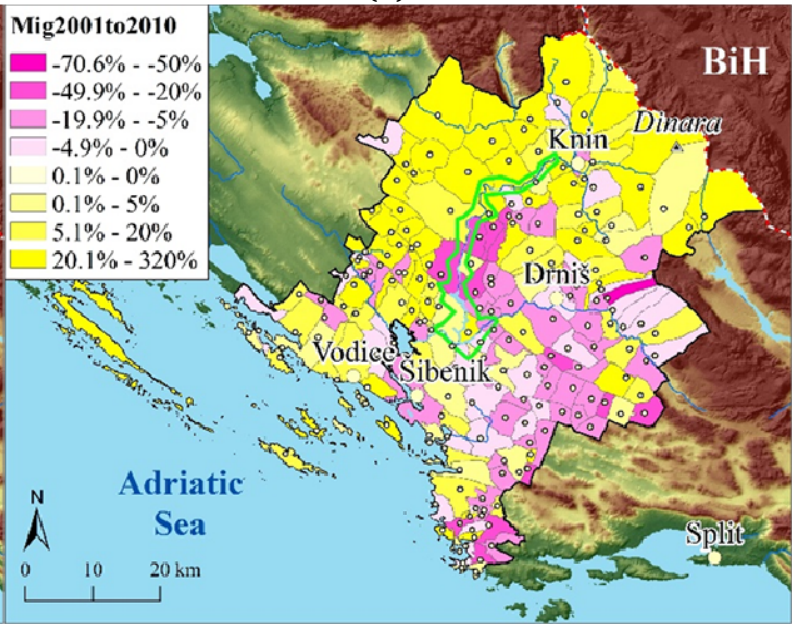

(d)

Fig. 1o Maps of migration relative values calculated by decade. A) 1971 to 1980 , B) 1981 to 1990 , C) 1991 to 2000 , D) 2001 to 2010. BiH: Bosnia and Herzegovina.

\subsection{Results of the correlation analysis}

The results of the study of the relationships between natural factors and selected demographic indicators are presented in Table 2, and the correlations that proved to be statistically significant are highlighted. The results calculated for the individual settlement data and the binned data gave broadly similar results in terms of significance; for the sake of better overview
Table 2 Spearman's correlation coefficients $(R)$ calculated using binned values. If the absolute value of $R$ is higher than the critical $R$ value, then the correlation is statistically significant at $\alpha=0.05$ (values in red).

\begin{tabular}{|l|l|l|l|l|l|l}
\hline Items & $Z$ & WatDist & SeaDist & NP_Dist & MeanSlope & MeanKarst \\
\hline number of bins & 12 & 11 & 12 & 17 & 13 & 13 \\
\hline critical R & 0.5760 & 0.6021 & 0.5760 & 0.4821 & 0.5529 & 0.5529 \\
\hline PopDens 1857 & 0.15 & -0.40 & 0.41 & 0.04 & 0.11 & -0.35 \\
\hline PopDens 1961 & -0.51 & -0.30 & -0.06 & 0.19 & -0.02 & -0.54 \\
\hline PopDens 2011 & -0.91 & -0.73 & -0.64 & 0.43 & -0.36 & 0.15 \\
\hline PopRatio 1961/1857 & -0.57 & 0.27 & -0.67 & -0.31 & -0.40 & 0.49 \\
\hline PopRatio 2011/1961 & -0.93 & -0.70 & -0.72 & 0.54 & -0.34 & 0.41 \\
\hline PopRatio 2001/1991 & -0.62 & -0.28 & -0.85 & 0.77 & -0.47 & 0.71 \\
\hline AgeIndex 2011 & 0.68 & 0.69 & 0.61 & 0.45 & 0.43 & 0.33 \\
\hline NatIncr 1971_1980 & 0.28 & -0.21 & 0.30 & -0.14 & 0.36 & -0.31 \\
\hline NatIncr 1981_1990 & -0.65 & -0.83 & 0.37 & -0.54 & 0.62 & -0.68 \\
\hline NatIncr 1991_2000 & -0.52 & -0.64 & 0.31 & -0.82 & -0.19 & -0.15 \\
\hline NatIncr 2001_2010 & -0.96 & -0.51 & -0.81 & 0.31 & -0.59 & 0.59 \\
\hline Mig 1971_1980 & -0.88 & -0.79 & -0.33 & -0.10 & -0.06 & -0.42 \\
\hline Mig 1981_1990 & -0.69 & -0.80 & 0.12 & -0.08 & -0.37 & 0.01 \\
\hline Mig 1991_2000 & -0.52 & -0.08 & -0.38 & -0.18 & -0.32 & -0.13 \\
\hline Mig 2001_2010 & 0.36 & -0.70 & 0.35 & 0.18 & 0.03 & -0.30 \\
\hline
\end{tabular}


we will only discuss the binned data.

In general, we found that, among natural factors, elevation (Z) shows the strongest relationship with almost all demographic indicators. There is a moderately strong correlation showing that the higher the elevation, the lower the population density in 2011, the higher the population decrease from 1961 to 2011 (especially in the 1990s), the older the population, the greater the natural decrease in the 80 s and 2000s, and the more negative the migration in the 1970 s and 1980 .

The second most important natural factor is distance from the water (WaterDist). Based on the significant correlations, we conclude that the farther we go from water (watercourse, lake, or sea), the lower the population density in 2011, the greater the population decline between 1961 and 2011, the older the population, the more negative the natural increase in the 1980s and 1990s, and the more negative the migration - except during the 1990s.

Somewhat surprisingly, distance from the sea (SeaDist) by itself is only the third-best explanatory variable for most demographics. Even so, it can be stated that the greater the distance from the sea, the lower the population density in 2011, the slower the population growth in the first half of the study period, and the faster the decline in the second half. This factor is closely linked to population change during the 1990s. But the degree of ageing and the natural increase of the 2000s also correlate with distance from the sea. Here we note that the distance from the sea is moderately strongly correlated $(r=0.74)$ with elevation at the settlement level. Incidentally, we found only weak or insignificant statistical correlations between other pairs of natural factors.

The other three factors (MeanKarst, NPDist, MeanSlope) still show a significant relationship with certain demographic parameters, but they have less explanatory power than the first three natural factors. The reasons for this vary. First, as with MeanKarst, the heterogeneities within the karst terrain cannot be explained by this factor alone, as a large part of the area is dominated by karstic rocks. Second, the existence of Krka NP does not seem to be particularly decisive in demographic processes. However, these two factors will be examined separately by other statistical methods. The effect of slope on demographic parameters is discussed in Section 4.

\subsection{Comparison of settlements based on categories: coastal and inland, partially- karst and fully-karst, and near to or far from Krka NP}

Comparisons were made by comparing a given class with the corresponding control class and by performing a Kolmogorov-Smirnov test to check the similarity of the distributions. The null hypothesis is that the distributions are equal, which is rejected if the

Table 3 Comparison of median values and distributions of "fully-karst" and "partially-karst" for coastal and inland areas; and comparison of settlements close to Krka NP and those located farther away. K-S: Kolmogorov-Smirnov. Distributions are significantly different at the $95 \%$ confidence level, if the $p$-value is less than 0.05 (in red). For further explanation see text.

\begin{tabular}{|c|c|c|c|c|c|c|c|c|c|}
\hline Items & $\begin{array}{l}\text { Partially- } \\
\text { Karst, } \\
\text { Coastal }\end{array}$ & $\begin{array}{l}\text { Fully- } \\
\text { Karst, } \\
\text { Coastal }\end{array}$ & $\begin{array}{l}\text { K-S test } \\
p \text {-value }\end{array}$ & $\begin{array}{l}\text { Partially-Karst, } \\
\text { Inland }\end{array}$ & $\begin{array}{l}\text { Fully-Karst, } \\
\text { Inland }\end{array}$ & $\begin{array}{l}\mathrm{K}-\mathrm{S} \\
\text { test } \\
p \text {-value }\end{array}$ & $\begin{array}{l}\text { NP Dist } \\
<2 \mathrm{~km}\end{array}$ & $\begin{array}{l}\text { NP Dist } \\
>2 \mathrm{~km}^{*}\end{array}$ & $\begin{array}{l}\text { K-S } \\
\text { test } \\
p \text {-value }\end{array}$ \\
\hline$n$ & 6 & 59 & & 33 & 98 & & 26 & 83 & \\
\hline PopDens 1857 & 7.7 & 11.6 & 0.1721 & 31.5 & 24.2 & 0.0172 & 27.4 & 24.8 & 0.5712 \\
\hline PopDens 1961 & 30.9 & 49.1 & 0.5421 & 56.5 & 42.3 & 0.0049 & 47.9 & 47.2 & 0.5814 \\
\hline PopDens 2011 & 22.8 & 27.0 & 0.6801 & 14.0 & 8.5 & 0.0897 & 11.9 & 13.0 & 0.7232 \\
\hline AgeIndex 2011 & $144 \%$ & $187 \%$ & 0.1751 & $340 \%$ & $304 \%$ & 0.7173 & $228 \%$ & $305 \%$ & 0.323 \\
\hline PopRatio 1961/1857 & $47 \%$ & $100 \%$ & 0.5537 & $71 \%$ & $62 \%$ & 0.2005 & $60 \%$ & $70 \%$ & 0.3329 \\
\hline PopRatio 2011/1961 & $-43 \%$ & $-48 \%$ & 0.9525 & $-78 \%$ & $-79 \%$ & 0.7179 & $-71 \%$ & $-76 \%$ & 0.5211 \\
\hline PopRatio 2001/1991 & $-12 \%$ & $-13 \%$ & 0.7611 & $-70 \%$ & $-53 \%$ & 0.0917 & $-51 \%$ & $-50 \%$ & 0.1820 \\
\hline NatIncr 1971_1980 & $3.1 \%$ & $-3.3 \%$ & 0.0105 & $1.0 \%$ & $-0.8 \%$ & 0.0331 & $-0.8 \%$ & $0.6 \%$ & 0.4359 \\
\hline NatIncr 1981_1990 & $3.1 \%$ & $-3.0 \%$ & 0.1977 & $-0.7 \%$ & $-3.7 \%$ & 0.0002 & $-4.4 \%$ & $-2.1 \%$ & 0.6159 \\
\hline NatIncr 1991_2000 & $-0.6 \%$ & $-4.6 \%$ & 0.5615 & $-2.5 \%$ & $-3.3 \%$ & 0.0190 & $-4.1 \%$ & $-2.5 \%$ & 0.1472 \\
\hline NatIncr 2001_2010 & $-6.8 \%$ & $-5.6 \%$ & 0.8180 & $-23.8 \%$ & $-17.6 \%$ & 0.2057 & $-15.4 \%$ & $-17.8 \%$ & 0.8640 \\
\hline Mig 1971_1980 & $-11.5 \%$ & $-16.4 \%$ & 0.5564 & $-14.5 \%$ & $-18.9 \%$ & 0.0704 & $-14.5 \%$ & $-16.7 \%$ & 0.4327 \\
\hline Mig 1981_1990 & $-12.7 \%$ & $1.0 \%$ & 0.5860 & $-7.6 \%$ & $-10.6 \%$ & 0.0140 & $-10.1 \%$ & $-9.2 \%$ & 0.5509 \\
\hline Mig 1991_2000 & $-11.4 \%$ & $-1.7 \%$ & 0.2205 & $-68.3 \%$ & $-42.7 \%$ & 0.0183 & $-37.6 \%$ & $-48.6 \%$ & 0.0685 \\
\hline Mig 2001_2010 & $7.8 \%$ & $1.0 \%$ & 0.5914 & $29.0 \%$ & $1.8 \%$ & 0.0257 & $2.7 \%$ & $2.4 \%$ & 0.1313 \\
\hline
\end{tabular}

Note: *: only those settlements are considered that have similar elevation and similar distance from the coast than the NP area. 
$p$-value is smaller than 0.05 at the $95 \%$ confidence level. Table 3 shows the median values for each group and each variable. Median values are presented because they reflect the population better than the mean values, which are often distorted by extreme values.

As shown in Sections 3.1 and 3.2, radically different demographic trends took place on the coast and in the interior. These override the karst effect and Krka NP effect, and statistical tests were performed so that the control group was similar to the group to be examined from the viewpoint of sea distance.

As a result, we found that there was no significant difference in the distribution of demographic indicators between "fully-karstic" and "partiallykarstic" settlements in the coastal zone, except for one indicator that expresses the natural increase/decrease in the 1970s. That is, the coast effect here is clearly stronger than the karst effect. On the other hand, the situation is different in the case of the interior. Here, for many demographic indicators, there is a remarkable difference between "partially-karst" and "fully-karst" areas. The aforementioned indicators are population density in 1857 and 1961, natural increase in the 1970s, 1980s, and 1990s, and the relative value of migration from the 1980 s onwards. With the exception of migration during the 1990 s, for all cases with significant difference, we can conclude that inland karst areas are "less-favourable" than partiallykarst areas, i.e. they are less densely populated, with more intense natural decrease and more significant out-migration.

Regarding the impact of Krka NP, the maps already suggested that there was no difference between the settlements nearby and those farther away with a similar elevation and at a similar distance from the coast. Statistical tests confirmed this observation because none of the demographic indicators showed a significant difference between settlements vis-à-vis proximity to Krka NP. Thus, we can conclude that Krka NP, which has existed since 1985 , does not have an effect on the settlements in its immediate vicinity that would significantly decelerate depopulation.

As for the effects of war (see Table 4), the differences between the occupied and non-occupied, inland "fully-karst" areas are quite obvious. The population density values are not significantly different according to the Kolmogorov-Smirnov test, however, while the population density median values of the occupied and non-occupied settlements were similar to each other in 1857 and in 1961, the non- occupied settlements had a much higher median population density than the occupied settlements in 2011. This is mainly due to the significantly more severe population decrease during the War. Before the War, the natural increase and migration parameters were significantly worse in the nonoccupied category (i.e. before the war effect, these settlements were more disadvantaged). However, the War had the opposite effect and the occupied settlements showed significantly higher negative values after the War, except for migration in the 2000s, as the formerly occupied settlements became targets of resettlement.

\section{Discussion}

Several previous studies proved that higher slope angles set certain limitations on settlements and found correlations between slope angle and population density. In fact, slope is among the most used factors for modelling population distribution, both on the global scale (Tian et al. 2005) and in regional studies (Yue et al. 2003, Schneiderbauer and Ehrlich 2005). Statistically significant correlations were found between population density and slope for the Gömör-Torna Karst in Hungary and Slovakia (Telbisz et al. 2015), between population density and slope for Apuseni Mts in Romania (Telbisz et al. 2016),

Table 4 The 1991-1995 war effect. Comparison of median values and distributions of "fully-karst", occupied and "fully-karst" non-occupied inland areas. K-S: Kolmogorov-Smirnov. Distributions are significantly different at the 95\% confidence level, if the $p$-value is less than 0.05 (in red). For further explanation see text.

\begin{tabular}{lllll} 
Items & \multicolumn{2}{l}{$\begin{array}{l}\text { Fully-Karst, Inland } \\
\text { Non-occupied }\end{array}$} & $\begin{array}{l}\text { K-S test } \\
p \text {-value }\end{array}$ \\
\hline$n$ & 40 & 58 & \\
\hline PopDens 1857 & 21.9 & 25.3 & 0.1691 \\
\hline PopDens 1961 & 41.5 & 42.6 & 0.4653 \\
\hline PopDens 2011 & 11.3 & 7.8 & 0.0917 \\
\hline AgeIndex 2011 & $268 \%$ & $422 \%$ & 0.0136 \\
\hline PopRatio 1961/1857 & $61.1 \%$ & $62.8 \%$ & 0.7492 \\
\hline PopRatio 2011/1961 & $-72.7 \%$ & $-82.9 \%$ & 0.0020 \\
PopRatio 2001/1991 & $-33.2 \%$ & $-65.2 \%$ & 0.0000 \\
\hline NatIncr 1971_1980 & $-1.1 \%$ & $-0.3 \%$ & 0.8533 \\
\hline NatIncr 1981_1990 & $-6.4 \%$ & $-2.2 \%$ & 0.0039 \\
\hline NatIncr 1991_2000 & $-6.8 \%$ & $-2.5 \%$ & 0.0017 \\
\hline NatIncr 2001_2010 & $-13.1 \%$ & $-21.6 \%$ & 0.0143 \\
\hline Mig 1971_1980 & $-25.6 \%$ & $-16.6 \%$ & 0.0014 \\
Mig 1981_1990 & $-16.1 \%$ & $-8.4 \%$ & 0.0404 \\
\hline Mig1991_2000 & $-29.9 \%$ & $-60.5 \%$ & 0.0000 \\
Mig 2001_2010 & $-8.0 \%$ & $17.2 \%$ & 0.0000
\end{tabular}


and between different population change parameters and slope for Kastamonu Forest in Turkey (Buğday and Özden 2017). However, in this study, it was found that the slope angle does not work well for the study area. The reason is that flat areas with good soil are favourable for human settlements, but the extended flat areas of karst plateaus are not. Therefore, there is a large variance of demographic data in flat areas. Furthermore, in the case of karst, the dissected parts provide somewhat better access to water, i.e. more favourable conditions. On the contrary, in the mountainous parts, the more dissected areas are less favourable for human settlement. Therefore, we cannot deduce an advantage or disadvantage for settlement from the slope angle alone, making correlations between the slope angle and demographic factors insignificant in most cases for Šibenik-Knin County.

Depopulation and ageing are indeed among the most important problems in the region, as in many other rural karstic, mountainous areas (cf. Telbisz et al. 2014, 2015). We found that the basic statements of geographical possibilism hold true for the study area. If geographical determinism was true, then we would have found similar social development trajectories throughout the entire study period, as the natural background was essentially unchanged. However, we found that migration directions have changed several times during the study period, and the aforementioned problems of depopulation or ageing emerged or became more severe only in the second half of the $2^{\text {th }}$ century, due to social transformations. This means that social processes are not fully determined by nature. On the other hand, the correlations and statistical tests proved that the natural environment sets certain constraints and limitations.

Social processes in the study area are quite complex, and modelling social parameters by simple correlations led to moderate results in terms of statistical significance. However, we believe that this type of analysis is useful in emphasising certain influential natural factors. In the present section, we explore the background of specific social processes more qualitatively.

As for the main reasons behind ageing, these were described by Mrđen and Barić (2016): low fertility rate, increase of life expectancy, migrations, economic crisis, and war. With regard to migration, emigration from littoral Croatia to overseas was already an ongoing process during the first decades of the $20^{\text {th }}$ century and was the likely reason behind the population decrease in the coastal strip and on the islands (cf. Nejašmić 1991; Lajić and Mišetić 2013). Out-migration from rural areas followed the decline of agriculture and the growth of industrialisation and later services-a global phenomenon that emerged here in the mid-1950s. At the same time, the number of migrant workers going to Western Europe from the former Yugoslavia also increased, as Yugoslavia was "more liberal" than other socialist countries of Eastern and Central Europe. Emigration to Western Europe as a worker (Gastarbeiter) was a typical phenomenon for the study area. War-related forced migrations of the 1990 s and the resettlements of the 2000 are relevant and were already mentioned in the previous section.

A noted phenomenon is population growth of Drniš and Knin until 1991, amid the general decline of inland territory in this part of Dalmatia. This can be explained by polarised development at the municipal level. Before the 1990s, the area of contemporary Šibenik-Knin County was organised into three large municipalities (Šibenik, Knin, and Drniš). Within the pre-1990s system of large municipalities in Croatia, municipal centres were often favoured and most functions were concentrated in them, leaving the smaller settlements undeveloped (Toskić and Njegač 2003). A partial exception was coastal municipalities, where some smaller settlements managed to keep or attain certain functions via tourism development (Glamuzina and Glamuzina 1998).

If we compare the demographic changes in the study area with the nearby Velebit Region, where two national parks (Paklenica NP and Northern Velebit NP) are found, we see that similar changes took place there, but even earlier and more drastically. The population in the Velebit area peaked in 1910, and since then there has been a steady decline, with a number of small settlements that have practically gone extinct (Pejnović and Husanović-Pejnović 2008). The reason for the difference might be, among other things, that Velebit is a much more mountainous area, making it demographically more disadvantaged. The fact that settlements in the mountains can go extinct more easily has been demonstrated by several authors (e.g. Toniolo 1937; Milošević et al. 2010, 2011; Kohler et al. 2017). Moreover, Devčić (2021) found that Northern Velebit NP and Paklenica NP (located in the southern section of Velebit Mountain) have had positive influences on economic development in the 
local area, especially for tourism. However, no effect was shown in terms of population change in settlements that are deeply depopulated, particularly in the case of Northern Velebit NP, where depopulation has served as a limiting factor for local tourism development (Devčić 2021).

The ageing and abandonment of settlements is a painful process and an acute organisational problem for social institutions. However, we note with caution that there may also be ecologically positive consequences for an area to become "closer to nature" (Grau and Aide 2007). Nonetheless, some authors have pointed out that the cessation of traditional agricultural cultivation in some areas may also lead to biodiversity impoverishment (Sitzia et al. 2010). As a consequence, the goal should not be to try to preserve every settlement in a state that is similar to what it was 50 years ago, because it would be futile. Instead, a mixed strategy would involve good planning of local development of disadvantageous regions. This strategy could be supported by a careful assessment of the impact of natural resources on society. However, elaboration of this kind of strategy is outside the scope of this paper.

For further comparison, we can look at the impact of other national parks on their surrounding settlements. A national park was established in 1960 on the nearby island of Mljet. According to a study by Šulc and Valjak (2012), this played a key role in slowing depopulation, however, it has amplified the discrepancy between the depopulating settlements in the island's interior and the extremely progressive coastal settlements with developed tourism. Furthermore, Šulc and Valjak (2012) noted that complete dependence on tourism and Mljet National Park is not favourable for further socio-economic development.

The statistical results presented in this article are consistent with the previous findings by Radeljak Kaufmann (2020) that the settlements near Krka National Park have often been characterised by depopulation and problems with socio-economic development. However, despite intense growth in tourist volume, Krka NP exercised almost no influence on the stabilisation of settlement patterns in this depopulated zone. Recently, however, recognising these problems, several initiatives have been launched. First, there was a park project (2015-2019) called "The Unknown Krka: the hidden treasures of the upper and lower course of the Krka River", which aimed to spatially distribute tourist traffic throughout Krka NP's area. The goal was to reduce congestion in the busiest sites, and to show the attractions of other settlements from the surroundings. There are also plans to establish new visitor centres outside Krka NP in nearby local communities. Furthermore, independent of Krka NP, rural tourism is also being strengthened, e.g. through EU-funded projects, which has resulted in a sevenfold increase in rural tourism in the last decade.

The primary task of the Park is, of course, the preservation of biotic and abiotic natural values and of biodiversity (the ecosystem). However, in the $21^{\text {st }}$ century, there is a growing attitude in both developed and developing countries that protected areas contribute to the social and economic well-being of the people living in the surrounding settlements (Mose 2007; Ezebilo and Mattsson 2010; Getzner 2010). However, the implementation of this principle is not easy. During their study performed in Cross River National Park, Nigeria, Ezebilo and Mattsson (2010) found that only one settlement benefitted directly from the Park's tourism revenues. According to Getzner (2010), the direct economic effects of protected areas are difficult to prove, but in the long run, protected areas can contribute to regional sustainable development in terms of improving infrastructure, favourable structural change, and benefits for the tourism industry. According to Kariyawasam et al. (2020), planning and management of national parks in Sri Lanka have not yet produced local development initiatives nor have local residents benefited to any significant extent from sharing mechanisms. On the other hand, there are examples where local communities acknowledge the benefits they enjoy due to tourism in protected areas. For instance, in a study at Kinabalu National Park (Malaysia), almost all of the respondents agreed that tourism development improved their earnings, living conditions, and public services. Local communities are either involved in businesses which are directly or indirectly related to tourism or employed in tourism businesses (Jaafar et al. 2013). So, the palette is really broad when we talk about the benefits national parks can provide to surrounding settlements. Moreover, demographic statistics alone are not enough to examine the complex social impact of karst national parks, but the recognition of stakeholders' opinions should also be explored in finer detail. Surveys with questionnaires and 
interviews have been conducted in relation to karst national parks in Hungary at Aggtelek National Park (Telbisz et al. 2020b), in Slovakia at Slovak Karst National Park (Nestorová-Dická et al. 2020), in Croatia at Paklenica National Park (Krpina 2015), Mljet National Park (Šulc and Valjak 2012), in Serbia at Tara National Park (Telbisz et al. 2021), in Vietnam at Ba Be National Park (Huong and Lee 2017), and many other national parks.

\section{Conclusions}

Using GIS and statistical analysis of demographic and natural data, we came to the following conclusions regarding the hypotheses formulated in the introduction. According to most indicators, the demographic development of the coastal and inland areas differs significantly throughout the study area, and this divergence has intensified (especially since the 1960s). The sea, as a natural factor, had a different effect on society in the $19^{\text {th }}$ century, when agriculture was more important and tourism was of little importance; while the importance of these economic sectors was reversed in the second half of the $2 \mathrm{O}^{\text {th }}$ century.

Although the coastal-inland dichotomy is dominant in the study area, our analysis revealed that elevation as a natural factor is even more closely related to demographic indicators than distance from the sea. However, contrary to the findings of many previous articles, slope angle, which expresses the land dissection, did not give good correlation results for the study area in this research. This is because, a significant proportion of flat areas in this predominantly karstic area, with the exception of poljes, is unfavourable for human settlement due to water scarcity and weak soils. This means that the variance of flat areas is high in terms of demographics, which ruins correlations.

We found a significant difference between the demographic processes of fully-karstic and partiallykarstic areas, and our findings agree with those of many previous studies; it has once again been proved in statistical terms that karst areas are more disadvantaged from a demographic point of view. However, the previous statements apply only to inland areas, as there is no significant difference between fully-karst and partially-karst areas in the coastal zone. In karst areas, the sparse drainage network is of particular importance, and the distance from surface waters (for which the minimum distance from land and sea was taken into account) showed a relatively close relationship with demographic characteristics.

As expected, the statistical correlations between natural and demographic factors are moderately strong. However, no significant temporal change was observed in the direction of the correlations. It is true that in the first half of the study period (1857-1961) the population increased in most places and in the second half (1961-2011) it decreased, but this did not change the character of significant relationships. Where growth was faster in the initial period, the decline started later and was milder. The only exception to this observation is the migration of the 2000s. The opposite processes during this decade can be traced back to the phenomena of post-war resettlement.

The impact of Krka National Park on the demographic characteristics of the surrounding settlements was not detectable. Thus, we cannot claim that Krka NP has retaining power for the population living nearby. On the one hand, this may be due to the fact that tourists come here from more distant accommodations (from the coast, or in many cases outside of Croatia). On the other hand, even park employees and those working in tourism often commute from nearby coastal settlements. Therefore, Krka NP's effect may be "hidden" in the coastal settlement statistics. Nonetheless, in order to increase the positive effects on the nearby settlements, the development of rural tourism has started and different initiatives have been undertaken to distribute Krka NP's tourists over a larger area instead of the crowded central location (Skradin waterfalls). As a part of our research project, we plan to conduct a questionnaire survey with local residents and tourists in Krka National Park, as well as interviews with park managers and local stakeholders to gain a deeper understanding of how protected areas can contribute to the sustainable development of the surrounding population.

\section{Acknowledgements}

This research has been supported by the National Research, Development and Innovation Office Hungary (NKFIH) K124497 Project. 


\section{Open Access}

This article is licensed under a Creative Commons Attribution 4.0 International License, which permits use, sharing, adaptation, distribution and reproduction in any medium or format, as long as you give appropriate credit to the original author(s) and the source, provide a link to the Creative Commons license, and indicate if changes were made. The images or other third party material in this article are included in the article's Creative Commons license, unless indicated otherwise in a credit line to the material. If material is not included in

\section{References}

CBS (Croatian Bureau of Statistics) (2013) Census of population, households and dwellings in 2011: Population by sex and age, by settlements. www.dzs.hr (accessed on 2020-10-22)

CBS (Croatian Bureau of Statistics) (2020) Towns in Statistics. www.dzs.hr (accessed on 2021-01-27)

CBS (Croatian Bureau of Statistics) (n.d. a) Settlements and population of the Republic of Croatia 1857-2001, SibenikKnin County - number of inhabitants by settlements. www.dzs.hr (In Croatian) (accessed on 2020-10-22)

CBS (Croatian Bureau of Statistics) (n.d. b) Data on births and deaths 1971-2010, Zagreb.

CGS (Croatian Geological Survey) (2009) Geological map of Croatia, scale 1:300.000, Zagreb.

Buğday SE, Özden S (2017) The relationship between terrain and rural migration (1965-2013) on the north of Turkey (the case of Kastamonu). Environ Monit Assess 189:154.

https://doi.org/10.1007/s10661-017-5867-9

Childs G, Craig S, Beall CM, et al. (2014) Depopulating the Himalayan highlands: education and outmigration from ethnically Tibetan communities of Nepal. Mt Res Dev 34:8595. https://doi.org/10.1659/MRD-JOURNAL-D-14-00021.1

Ciglič R, Hrvatin M, Komac B, et al. (2012) Karst as a criterion for defining areas less suitable for agriculture. Acta Geogr Slov 52:61-98. https://doi.org/10.3986/AGS52103

Devčić A (2021) The Impact of Paklenica and Northern Velebit National Parks on Local Development. Master Thesis. University of Zagreb, Faculty of Science, Department of Geography. (In Croatian)

Du F, Xiong K, Gao H (2008) Karst cultural tourism resources and their exploitation - A case study in Guizhou province. Carsologica Sinica 1:86-90.

https://doi.org/10.3969/j.issn.1001-4810.2008.01.015

Ewald J (2003) The calcareous riddle: Why are there so many calciphilous species in the Central European flora? Folia Geobot 38:357-366. https://doi.org/10.1007/BFo2803244

Ezebilo EE, Mattsson L (2010) Socio-economic benefits of protected areas as perceived by local people around Cross River National Park, Nigeria. Forest Policy Econ 12:189-193. https://doi.org/10.1016/j.forpol.2009.09.019

Gams I (1993) Origin of the term "karst", and the transformation of the classical karst (kras). Geo 21:110-114. https://doi.org/10.1007/BFoo775293

Getzner M (2010) Impacts of protected areas on regional sustainable development: the case of the Hohe Tauern national park (Austria). Int J Sustain Econ 2:419-441. https://doi.org/10.1504/IJSE.2010.035488

GISData (2008) Digital Atlas of the Republic of Croatia (GIS shapefiles), Zagreb, CD-ROM.

Glamuzina M, Glamuzina N (1996) Changes in the biological the article's Creative Commons license and your intended use is not permitted by statutory regulation or exceeds the permitted use, you will need to obtain permission directly from the copyright holder. To view a copy of this license, visit http://creativecommons.org/licenses/by/4.o/.

Funding note: Open access funding provided by Eötvös Loránd University. and economic structure of the population of Southern Croatia (Dalmatia) from 1948 to 1991. Geoadria 1:17-34. (In Croatian) https://doi.org/10.15291/geoadria.571

Grau HR, Aide TM (2007) Are rural-urban migration and sustainable development compatible in mountain systems? Mt Res Dev 27:119-124.

https://doi.org/10.1659/mrd.0906

Gregory D, Johnston R, Pratt G, et al. (2009) The Dictionary of Human Geography, 5th Edition | Wiley, 5th edn. WileyBlackwell.

Hamilton-Smith E (2007) Karst and world heritage status. Acta Carsol 36:291-302.

https://doi.org/10.3986/ac.v36i2.198

Huong PM, Lee JH (2017) Finding important factors affecting local residents' support for tourism development in $\mathrm{Ba} \mathrm{Be}$ National Park, Vietnam. Forest Sci Technol 13:126-132. https://doi.org/10.1080/21580103.2017.1354337

Jaafar M, Kayat K, Tangit TM, et al. (2013) Nature - based rural tourism and its economic benefits: a case study of Kinabalu National Park. Worldw Hosp Tour Themes 5:342-352.

https://doi.org/10.1108/WHATT-03-2013-0016

Kariyawasam S, Wilson C, Rathnayaka LIM, et al. (2020) Conservation versus socio-economic sustainability: A case study of the Udawalawe National Park, Sri Lanka. Environ Dev 35:100517.

https://doi.org/10.1016/j.envdev.2020.100517

Koderman M, Opačić VT (eds.) (2020) Challenges of tourism development in protected areas of Croatia and Slovenia. University of Primorska Press and Croatian Geographical Society, Koper. pp 9-16.

Kohler T, Elizbarashvili N, Meladze G, et al. (2017) The demogeographic crisis in Racha, Georgia: Depopulation in the central caucasus mountains. Mt Res Dev 37:415-425. https://doi.org/10.1659/MRD-JOURNAL-D-17-00064.1

Krpina V (2015) Analysis of the relation between visitors and protected natural areas in the Zadar County. Sumar List 139:535-551

Lajić I, Mišetić R (2013) Demographic changes on croatian islands at the beginning of the 21st Century. Migracijske $\mathrm{i}$ etničke teme (Migration and Ethnic Themes) 29:169-199. https://doi.org/10.11567/met.29.2.3

Latocha A (2012) Changes in the rural landscape of the Polish Sudety Mountains in the post-war period. Geogr Pol 85:13-21. https://doi.org/10.7163/GPol.2012.4.21

Lukić A (2012) Mosaic outside the city - a typology of rural and urban settlements in Croatia. Meridijani, Samobor. p 256. (In Croatian)

Lukić-Tanović M, Golijanin J, Šušnjar S (2019) Impact of 
population on the karst of East Sarajevo (Bosnia and Herzegovina). J Geogr Inst Jovan Cvijic SASA 69:95-107.

MacDonald D, Crabtree JR, Wiesinger G, et al. (2000) Agricultural abandonment in mountain areas of Europe: Environmental consequences and policy response. J Environ Manage 59:47-69. https://doi.org/10.1006/jema.1999.0335

Massey D, Allen J (eds.) (1984) Geography Matters!: A Reader. Cambridge University Press, Cambridge. p 216.

Mercier G (2009) Vidal de la Blache, P. In: Kitchin R, Thrift N (eds.) International Encyclopedia of Human Geography. Elsevier, Oxford. pp 147-150.

Milošević MV, Milivojević M, Ćalić J (2010) Spontaneously abandoned settlements in Serbia, Part 1. J Geogr Inst Jovan Cvijic SASA 60:39-57.

https://doi.org/10.2298/IJGI1002039M

Milošević MV, Milivojević M, Ćalić J (2011) Spontaneously abandoned settlements in Serbia, Part 2. J Geogr Inst Jovan Cvijic SASA 61:25-35.

https://doi.org/10.2298/IJGI1102025M

Mose I (2007) Protected Areas and Regional Development in Europe: Towards a New Model for the 21st Century. Ashgate Publishing Ltd., Aldershot, UK. p 272.

Mrđen S, Barić D (2016) Demographic ageing of the population in the County of Šibenik-Knin: grandparent boom. Geoadria 21:113-142

Nejašmić I (1991) Depopulacija u Hrvatskoj: Korijeni, stanje, izgledi (Depopulation in Croatia: Roots, Condition, Prospects) Globus, Zagreb. p 344. (In Croatian)

Nestorová Dická J, Gessert A, Bryndzová L, et al. (2020) Behavioural survey of local inhabitants' views and attitudes about Slovak Karst National Park in Slovakia. Sustainability 12:10029. https://doi.org/10.3390/su122310029

Opačić VT (2012) Vikendaštvo u hrvatskom priobalju: jučer, danas, sutra (Weekends on the Croatian coast: yesterday, today, tomorrow). Hrvatska sveučilišna naklada (Croatian University Press), Zagreb. p 301. (In Croatian)

Patterson LA, Doyle MW (2011) Hypsographic demography across scale. Prof Geogr 63:514-530.

https://doi.org/10.1080/00330124.2011.578534

Pejnović D (2004) Depopulacija županija i disparitet u regionalnom razvoju Hrvatske (County depopulation and disparity in Croatian regional development). Društvena istraživanja (Journal of Social Research) 13:701-726. (In Croatian)

Pejnović D, Husanović-Pejnović D (2008) Causes and consequences of demographic development in the territory of Velebit Nature Park, 1857-2001. Period Biol 110:195-204

Rabus B, Eineder M, Roth A, et al. (2003) The shuttle radar topography mission-a new class of digital elevation models acquired by spaceborne radar. ISPRS J Photogramm Remote Sens 57:241-262.

https://doi.org/10.1016/So924-2716(02)oo124-7

Radeljak Kaufmann P (2016) Challenges of the regional development in Dalmatia. Studia Miejskie (City studies) 24:107-127

Radeljak Kaufmann P (2020) Rural tourism in the surroundings of Krka National Park: factors of development and spatial impacts. In: Koderman M, Opačić VT (eds.), Challenges of Tourism Development in Protected Areas of Croatia and Slovenia. Založba Univerze na Primorskem/University of Primorska Press; Hrvatsko geografsko društvo/Croatian Geographical Society, Koper; Zagreb. pp 53-73. (In Croatian)

Rakić R, Dubravica B (2009) A brief overview of military activities in the Homeland War: 1991-1995. Ministry of Defense of the Republic of Croatia, Armed Forces of the Republic of Croatia, Croatian Military Academy Petar Zrinski, p 312. (In Croatian)

Ruban D (2018) Karst as important resource for geopark-based tourism: Current state and biases. Resources 7:82. https://doi.org/10.3390/resources7040082

Schneiderbauer S, Ehrlich D (2005) Population density estimations for disaster management: Case Study Rural Zimbabwe. In: van Oosterom P, Zlatanova S, Fendel EM (eds.), Geo-Information for Disaster Management. Springer, Berlin, Heidelberg. https://doi.org/10.1007/3-540-27468-5_64

Sitzia T, Semenzato P, Trentanovi G (2010) Natural reforestation is changing spatial patterns of rural mountain and hill landscapes: A global overview. For Ecol Manag 259:1354-1362.

https://doi.org/10.1016/j.foreco.2010.01.048

Small C, Cohen J (2004) Continental physiography, climate, and the global distribution of human population. Curr Anthropol 45:269-277.

https://doi.org/10.1086/382255

Šulc I, Valjak V (2012) Zaštićena područja u funkciji održivog razvoja hrvatskog otočja - primjer otoka Mljeta (Protected areas in the function of sustainable development of the Croatian archipelago - the example of the island of Mljet). Croat Geogr Bull 74:161-185. (In Croatian)

Telbisz T, Bottlik Z, Mari L, et al. (2014) The impact of topography on social factors, a case study of Montenegro. J Mt Sci 11:131-141.

https://doi.org/10.1007/s11629-012-2623-z

Telbisz T, Bottlik Z, Mari L, et al. (2015) Exploring relationships between Karst terrains and social features by the example of Gömör-Torna Karst (Hungary-Slovakia). Acta Carsol 44:121137. https://doi.org/10.3986/ac.v44i1.1739

Telbisz T, Brankov J, Calić J (2020a) Topographic and lithologic controls behind mountain depopulation in Zlatibor District (Western Serbia). J Mt Sci 17:271-288. https://doi.org/10.1007/s11629-019-5861-5

Telbisz T, Ćalić J, Kovačević-Majkić J, et al. (2021). Karst Geoheritage of Tara National Park (Serbia) and Its Geotouristic Potential. Geoheritage 13(4): 1-18. https://doi.org/10.1007/s12371-021-00612-5

Telbisz T, Gruber P, Mari L, et al. (2020b) Geological Heritage, Geotourism and Local Development in Aggtelek National Park (NE Hungary). Geoheritage 12:5. https://doi.org/10.1007/s12371-020-00438-7

Telbisz T, Imecs Z, Mari L, et al. (2016) Changing humanenvironment interactions in medium mountains: the Apuseni Mts (Romania) as a case study. J Mt Sci 13:1675-1687. https://doi.org/10.1007/S11629-015-3653-0

Telbisz T, Mari L (2020) The significance of karst areas in European national parks and geoparks. Open Geosci 12:117132. https://doi.org/10.1515/geo-2020-00o8

Telbisz T, Stergiou CL, Mindszenty A, et al. (2019) Karst features and related social processes in the region of the Vikos Gorge and Tymphi Mountain (Northern Pindos National Park, Greece). Acta Carsol 48:29-42. https://doi.org/10.3986/ac.v48i1.6806

Tian Y, Yue T, Zhu L, et al. (2005). Modeling population density using land cover data. Ecol Modell 189(1-2):72-88. https://doi.org/10.1016/j.ecolmodel.2005.03.012

Toniolo AR (1937) Studies of depopulation in the mountains of Italy. Geogr Rev 27:473-477. https://doi.org/10.2307/210332

Toskić A, Njegač D (2003) Changes in political and territorial organization and their impact on croatia's urban system and regional development. Hrvat Geogr Glas 65:7-20. https://doi.org/10.21861/HGG.2003.65.01.01

Wang C, Zhang Y, Yang Y, et al. (2019) What is driving the abandonment of villages in the mountains of Southeast China? Land Degrad Dev 30:1183-1192. https://doi.org/10.1002/ldr.3303

Yue TX, Wang YA, Chen SP, et al. (2003) Numerical simulation of population distribution in China. Popul Environ 25:141-163. https://doi.org/10.1023/B:POEN.ooooo15562.88915.01 